\title{
THE INFLUENCE OF A PURCHASING GROUP ON THE PROFITABILITY OF COMMERCIAL COMPANIES
}

\begin{abstract}
The aim of the paper was to present what influence on the profitability of commercial companies has their functioning in branch purchasing groups. In the article the definitions and the essence of purchasing groups were presented. Their division was made and there were featured the benefits of traders operating in branch purchasing groups. The article presents the role and function of the central unit appointed by the companies in the purchasing group. There were also presented barriers faced by companies that want to join purchasing groups. The next parts of the article concern the key issues related to profitability. There were identified key indicators for measuring the intensity of profitability. There were also discussed their structures and determinants of the rate of return of revenue from sales of assets and equity. Then on the example of commercial companies operating in the branch purchasing group it was shown what facilities commercial companies operating in the industry purchasing group receive. The main benefits that companies gain are primarily a low purchase price of goods and attractive period for trade credit. Both of these elements plus the economies of scale allow traders operating in the branch purchasing group, to a large extent, reduce costs and increase operating revenues. Increased sales and optimization of cost levels as a result of joint action have a positive effect on the profitability of the company.
\end{abstract}

Keywords: group purchasing, profit, profitability, costs

\section{INTRODUCTION}

Managers of companies primarily seek to provide a unit with individual financial resources which allow it to produce and sell the range of goods without unnecessary stopovers. Ensuring liquidity is the first basic step that allows the company to grow steadily and build competitive advantage. Another important issue the managers should pay attention to is not the profitability of the business, or the ability to make a profit. Companies operate just to generate profits. The sales advantage occurs when the price obtained from the sales of products of is higher than the costs incurred on their manufacture, or when the sales price of goods exceeds their purchase price. When these conditions are met, it is worth to sell because it's profitable ${ }^{2}$, then such a company is profitable to run. Ensuring high profitability is particularly important for owners of the company. This is an opportunity for dividends for them. Therefore, they care to have high profits. Profits for the company are also the funds for further development. Their absence in the long run leads to the collapse of the company. One of the most popular solutions

\footnotetext{
${ }^{1}$ Grzegorz Zimon, PhD, Eng., Department of Finance and Accounting, Rzeszów University of Technology, Rzeszów

${ }^{2}$ W. Gabrusewicz (2014), Analiza finansowa przedsiębiorstwa. Teoria i zastosowanie, PWE, Warszawa, p.301
} 
that significantly affects the size of revenues and expenses is functioning in the framework of purchasing groups. Common operations within the purchasing groups are small restrictions, but above all the advantages that allow companies to increase profits.

\section{PURCHASING GROUPS}

There are many definitions of purchasing groups. However, in order to submit properly their definitions one should distinguish two concepts, namely group shopping and purchasing group. Very often one may encounter a situation when several companies are working together and perform a purchase. This type of action should be defined as the group shopping, i.e. a common action in order to purchase merchandise, products, materials or services without creating a special unit supervising and without additional restrictions imposed on individual participants for the transaction. It is very popular now to get low prices. Another term is the purchasing group. To make a correct definition of the purchasing group one needs first to define what is meant by the word organization. The organization is "a team of people equipped with the appropriate measures, appointed to perform tasks to achieve better results than those generated by these people individually" 3 . Common actions within the organization allow first of all to get better results. The purchasing group can be described as a group of companies from the same or another branch which combine to make common purchases ${ }^{4}$. This is a very simplified definition of this type of organization. Another definition defines the group purchasing as a group of cooperating companies. They are managed by a specially created central unit whose aim is the realization of tasks commissioned by the companies making up the purchasing group ${ }^{5}$. Performing these tasks is to ensure better financial performance and security companies creating a purchasing group (Fig. 1). A wider definition of the purchasing group is based on the definitions of logistics and supply chain by Christopher Martin and it says that a purchasing group is a group of cooperating companies, which commonly control and improves the factual, informative and cash flows from suppliers to end customers. The participants of this system create a separate central unit, whose main task is to achieve the objectives set out by the companies in the system ${ }^{6}$.

\footnotetext{
${ }^{3}$ Bogdanienko, J. (ed.) (2010). Organizacja i zarzadzanie w zarysie, Warszawa: WWZ, p.129

${ }^{4}$ Zimon, G.,(2015), Wpływ grupy marketingowo-zakupowej na sytuacje i wyniki finansowe przedsiębiorstw, W: Z. Luty, M. Chmielowiec-Lewczuk, (ed.). Prace Naukowe Uniwersytetu Ekonomicznego we Wrocławiu no. 390, Rachunkowość, polityka makroekonomiczna, globalizacja, Wrocław: Wydawnictwo UE we Wrocławiu, p.287

${ }^{5}$ Zimon, G., (2014)., Kapitał obrotowy brutto w przedsiębiorstwach handlowych tworzących grupy zakupowe, W: I.D. Czechowskiej, R.Pastusiaka (ed.). Acta Universitatis Lodziensis, Folia Oconomica 2(300), Łódź: Wydawnictwo Uniwersytetu Łódzkiego, Łódź, p.319

${ }^{6}$ Zimon, G., (2014)., Kapitał obrotowy brutto w przedsiębiorstwach handlowych tworzących grupy zakupowe, W: I.D. Czechowskiej, R.Pastusiaka (ed.). Acta Universitatis Lodziensis, Folia Oconomica 2(300), Łódź: Wydawnictwo Uniwersytetu Łódzkiego, Łódź , p.320
} 


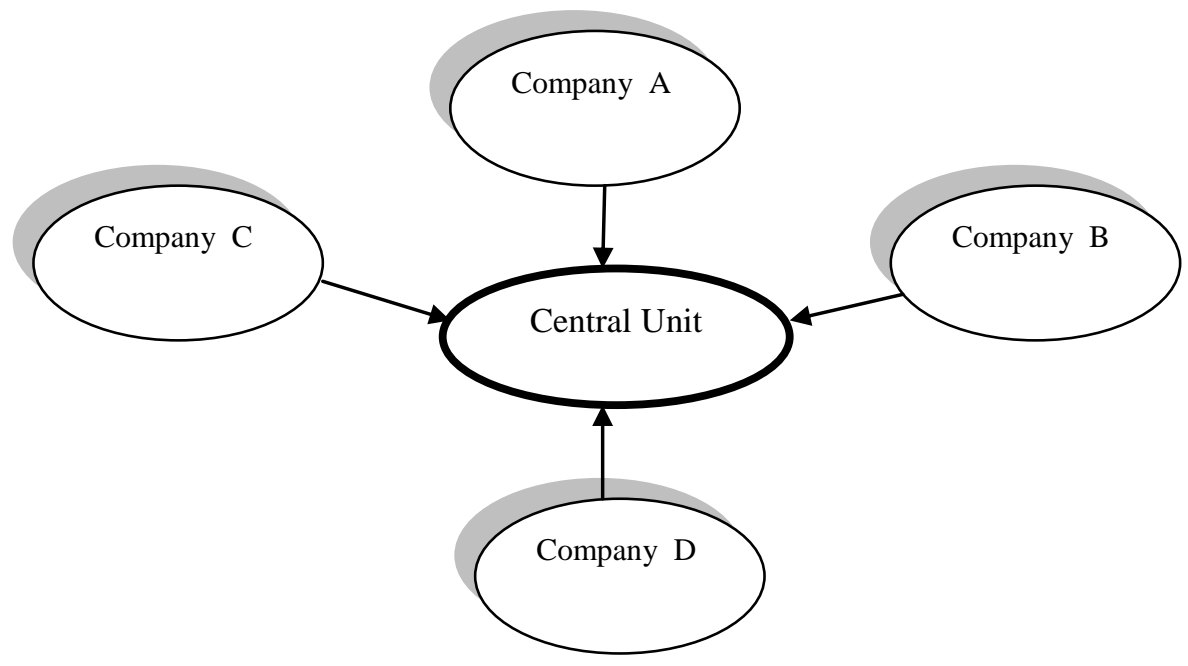

Fig. 1 Organization scheme of a purchasing group

Source: own research

Purchasing groups are managed by a specially created central unit whose aim is the realization of tasks commissioned by the companies making up the purchasing group ${ }^{7}$. The execution of these tasks is to ensure better financial performance, competitive advantage and safety for companies creating a purchasing group ${ }^{8}$. The objectives the central unit has to execute stretch far beyond making common purchases. Today, for the common business there are created: a coherent strategy for the development of companies, unified marketing, a new brand new, common sales and logistics. But the main purpose of creating purchasing groups is the use of economies of scale when purchasing. Purchasing groups can be described as powerful buyers. They meet the criteria that are characteristic for powerful buyers ${ }^{9}$ :

- Buy a large quantities,

- Products purchased in the sector are standardized,

- Products purchased in a given sector by a group of buyers are an important part of its costs.

\footnotetext{
${ }^{7}$ Zimon, G.,(2015), Wpływ grupy marketingowo-zakupowej na sytuacje i wyniki finansowe przedsiębiorstw, W: Z. Luty, M. Chmielowiec-Lewczuk, (ed.). Prace Naukowe Uniwersytetu Ekonomicznego we Wrocławiu no. 390, Rachunkowość, polityka makroekonomiczna, globalizacja, Wrocław: Wydawnictwo UE we Wrocławiu, p.287

${ }^{8}$ Zimon, G.,(2015), Wpływ grupy marketingowo-zakupowej na sytuacje i wyniki finansowe przedsiębiorstw, W: Z. Luty, M. Chmielowiec-Lewczuk, (ed.). Prace Naukowe Uniwersytetu Ekonomicznego we Wrocławiu no. 390, Rachunkowość, polityka makroekonomiczna, globalizacja , Wrocław: Wydawnictwo UE we Wrocławiu, p.287

${ }^{9}$ Porter, M.(2001). Porter o konkurencji, Warszawa: PWE, p.78
} 
The functioning on the market as powerful purchasers makes that every manufacturer cannot ignore such type of organization. They cannot afford to lose this client. It is worth noting that in purchasing groups the central unit, in addition to the realization of purchases, undertakes a marketing activity for all participants included in the group. The differentiation of tasks makes the basic division of groups into the purchasing and marketing-purchasing ones ${ }^{10}$.

Another important division in terms of efficiency analysis of purchasing groups is the division due to the selection of participants into the branch and multi-branch groups. This division is important because of the intensity of the most important features for the assumed purchasing groups, i.e. the economies of scale.

In the branch purchasing groups the companies operate within only a single branch. There are no other branches. It has positive significance to increase the "power buy" economies of scale. Companies operating in this type of group order the same type of goods. This limits the range of suppliers to the minimum number e.g. two or three. Limitation of suppliers makes that the scale of the order is large. The central unit negotiates in such a case the conditions of purchase for the branch purchasing group. It has a strong advantage in the form of the size of the order which the supplier (producer) must be reckoned with.

In case of multi-branch purchasing groups this scale effect is less visible. In this type of organization the traders in case of multiple orders are divided into smaller groups. Then, when one introduces two or three suppliers for the same range, then the fragmentation of the participants in a given order is large. It all makes that the scale effect, which is the most important "weapon" in the struggle with competitors, is not fully used. ${ }^{11}$

When analyzing the formation of purchasing groups, the division because of the integrated unit, i.e. into the Internet and traditional ones, should be done. The detailed division is shown in Fig. 2.

Joining the purchasing group is not easy. There are some barriers to join which must be observed if the companies operating in this type of organization want to build a competitive advantage. The most important are:

- Territorial barriers, this restriction is due to the fact that in the area there cannot be several companies operating in the same purchasing group. This restriction allows the company operating in the area to compete effectively with other units. Lack of this restriction would allow to create more units in a given area with similar competitive strength, which would limit the financial results of both units.

- Economic barriers, here are limitations associated with the turnover that companies should pursue.

- Environmental barriers, it is important the opinion of environment on the company.

\footnotetext{
${ }^{10}$ Zimon, G.,(2015), Wpływ grupy marketingowo-zakupowej na sytuacje i wyniki finansowe przedsiębiorstw, W: Z. Luty, M. Chmielowiec-Lewczuk, (ed.). Prace Naukowe Uniwersytetu Ekonomicznego we Wroctawiu no. 390, Rachunkowość, polityka makroekonomiczna, globalizacja pp.284-290, Wrocław: Wydawnictwo UE we Wrocławiu, p.287

${ }^{11}$ Zimon, G.,(2015), Wpływ grupy marketingowo-zakupowej na sytuacje i wyniki finansowe przedsiębiorstw, W: Z. Luty, M. Chmielowiec-Lewczuk, (ed.). Prace Naukowe Uniwersytetu Ekonomicznego we Wrocławiu no. 390, Rachunkowość, polityka makroekonomiczna, globalizacja pp.284-290, Wrocław: Wydawnictwo UE we Wrocławiu, p.287
} 
- Positive recommendation of the group members, individual members of the integrated delivery system must accept the new unit.

- Type of business activity in the branch purchasing groups - only those companies that operate in the same industry are allowed to operate. In the multi-branch groups there is no such restriction

It is clearly visible that not everyone can join a particular purchasing group. Lack of reaction in case of the above guidelines will not allow companies operating in purchasing groups to gain advantage over local competitors.

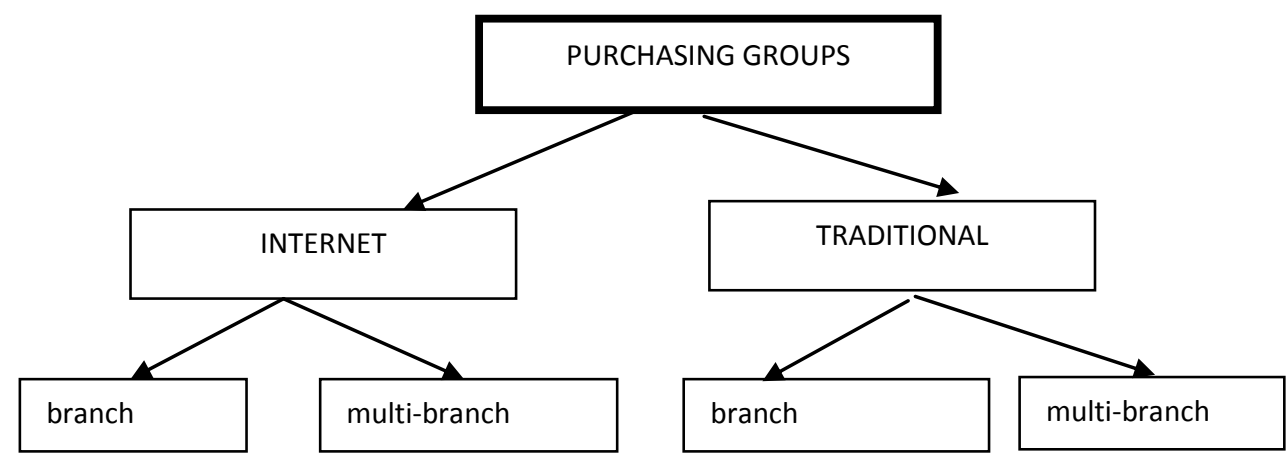

Fig. 2. Classification of purchasing groups

Source by Zimon G., 2013, Płynność finansowa w przedsiębiorstwach tworzących grupy zakupowe, [in:] Prace Naukowe Uniwersytetu Ekonomicznego We Wroclawiu 321 Zarządzanie finansami firm-teoria i praktyka , (ed.) Kopiński A., Kowalik P., Wydawnictwo Uniwersytetu Ekonomicznego we Wrocławiu, Wrocław, p.212

\section{PROFITABILITY}

One of the most important tasks the company should pursue is profit-making. Without a profit the company will fall in the long run. Profit is the basic measure of the business profitability. The information on whether the company has obtained a profit or loss is determined by financial results. The financial result as a size does not provide a basis for assessing the effectiveness of business management. It gives only the answer whether at the time the company obtained profit or loss. On the other hand, the ratio of profit to various financial categories, such as capital assets or the sales allows the formulation of financial conclusions ${ }^{12}$. One of the most popular methods of assessing the profitability of the company is to analyze its profitability. Profitability is the company's ability to generate profit ${ }^{13}$. The viability is based on the analysis of the profit generated by the entity in the period considered. Profitability ratios allow to measure the efficiency of the

\footnotetext{
${ }^{12}$ A. Kusak, (2006) Decyzje finansowe firmy. Metody analizy, C.H. Beck, Warszawa 2006, p. 3

${ }^{13}$ W. Gabrusewicz,( 2014) Analiza finansowa przedsiębiorstwa, PWE, Warszawa 2014, p. 296
} 
company's activities by reference to the profits of sales of assets and the contribution of equity. An analysis of viability is considered one of the most important as: ${ }^{14}$

1. Indicates the degree of multiplication of capital owners,

2. Expresses the function for the company, which all the other business areas such as liquidity, performance should be consistent with,

3. Enables to demonstrate the factors affecting the value for the owners.

Profitability analysis is recommended in the study on business continuity by an expert auditor. While analyzing the profitability, companies frequently use basic indicators of profitability:

- The return on sales,

- The return on total assets,

- The return on equity

Sales profitability ratio indicates the profitability of sales. A desirable phenomenon is when it is high. It shows what level of profit the company generates per unit of net sales. The most important factors determining the rate of return on sales revenue is the size and strength of competition, prices and sales volume in a given area or the relationship between the company and the market. The details are shown in Fig. 3. ${ }^{15}$

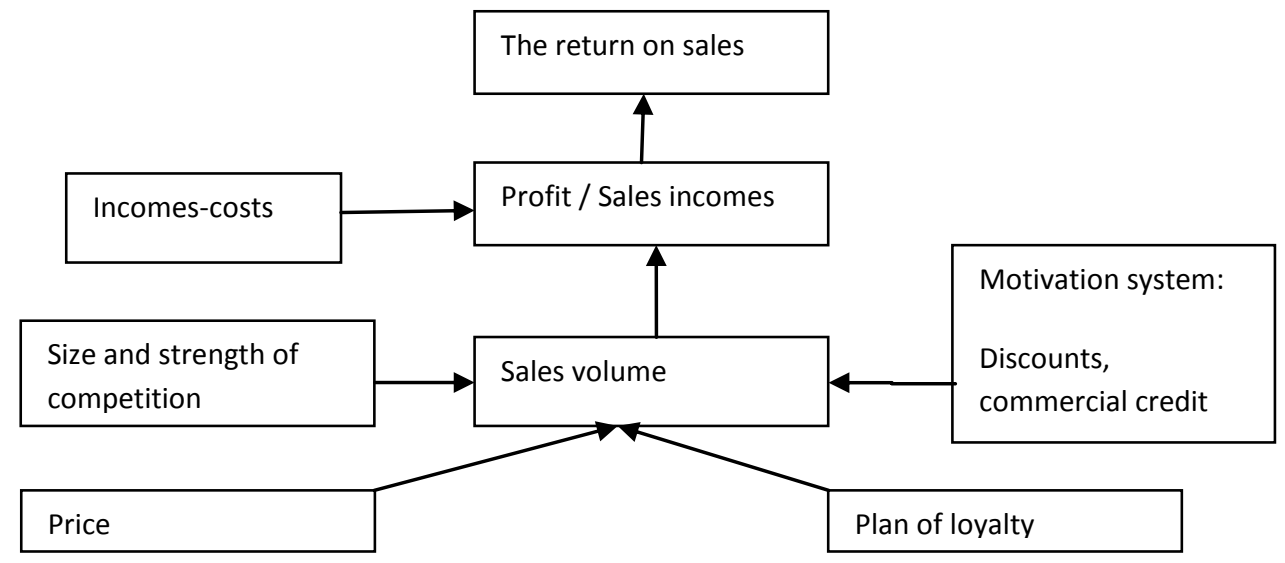

Fig. 3. Determinants of return on sales revenue Source: own study

The basis for running a company is its property ${ }^{16}$. Therefore, the involvement of individual assets should be optimal. A tool that provides information about the effectiveness of the use of property is the return on assets (ROA). It determines the ability

\footnotetext{
${ }^{14}$ D. Wędzki., ( 2006) Analiza wskaźnikowa sprawozdania finansowego, Kluger, Kraków 2006, p. 429

15 Chłodnicka H., Zimon G. (2013): Wpływ kosztów upadłości na rentowność podmiotu gospodarczego, W: E. Nowak, M. Nieplowicz, (ed.) Prace Naukowe Uniwersytetu Ekonomicznego we Wrocławiu, z.291, Rachunkowość a controlling, pp.66-81, Wydawnictwo Uniwersytetu Ekonomicznego we Wrocławiu

${ }^{16}$ Nowak E., Analiza sprawozdań finansowych, PWE, Warszawa 2005, p.169
} 
of the company's assets to generate profit. The factors determining the rate of return on assets is shown in Fig. $4 .^{17}$

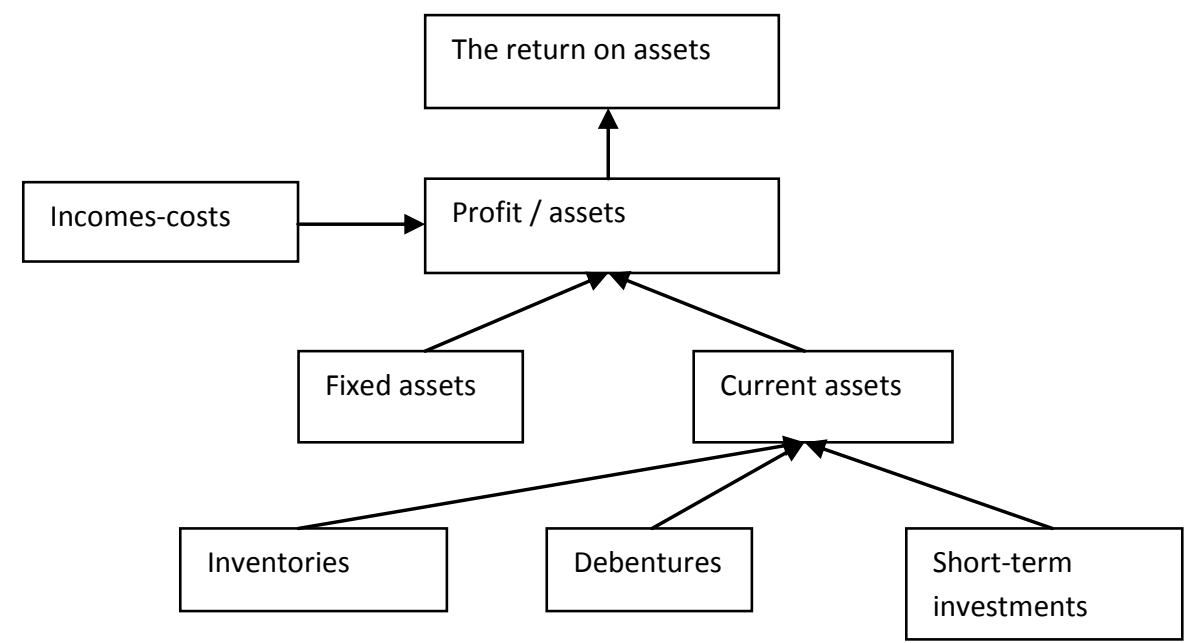

Fig. 4. Determinants of return on assets revenue

Source: own study based upon P. Karpuś „, Zarządzanie finansami przedsiębiorstw' UMCS Lublin, 2006, p.79

The last basic rate is a rate of return on equity. It is the ratio of profit to equity. It shows the level of profit generating unit equity. The problem with this rate is the precise value of equity. In the balance sheet liabilities in the group $\mathrm{A}$ it includes a number of different elements, such as e.g. the current profit, which only temporarily in such amount may be from the company, therefore one needs to pay special attention to determine the value of equity ${ }^{18}$. The level of this rate is also influenced by the effectiveness of asset management (especially working capital, negligence in this regard and bad management strategy leads to unnecessary costs), the level of sales and cost of products sold. The factors determining the rate of return on assets are shown in Fig. $5^{19}$.

17 Chłodnicka H., Zimon G. (2013): Wpływ kosztów upadłości na rentowność podmiotu gospodarczego, W: E. Nowak, M. Nieplowicz, (ed.) Prace Naukowe Uniwersytetu Ekonomicznego we Wrocławiu, z.291, Rachunkowość a controlling, pp.66-81, Wydawnictwo Uniwersytetu Ekonomicznego we Wrocławiu

${ }^{18}$ T.Waśniewski, W.Skoczylas, Teoria i praktyka analizy finansowej $w$ przedsiębiorstwie, FRR w Polsce, Warszawa 2004, s.171

19 Chłodnicka H., Zimon G. (2013): Wpływ kosztów upadłości na rentowność podmiotu gospodarczego, W: E. Nowak, M. Nieplowicz, (red) Prace Naukowe Uniwersytetu Ekonomicznego we Wrocławiu, z.291, Rachunkowość a controlling, s.66-81, Wydawnictwo Uniwersytetu Ekonomicznego we Wrocławiu 


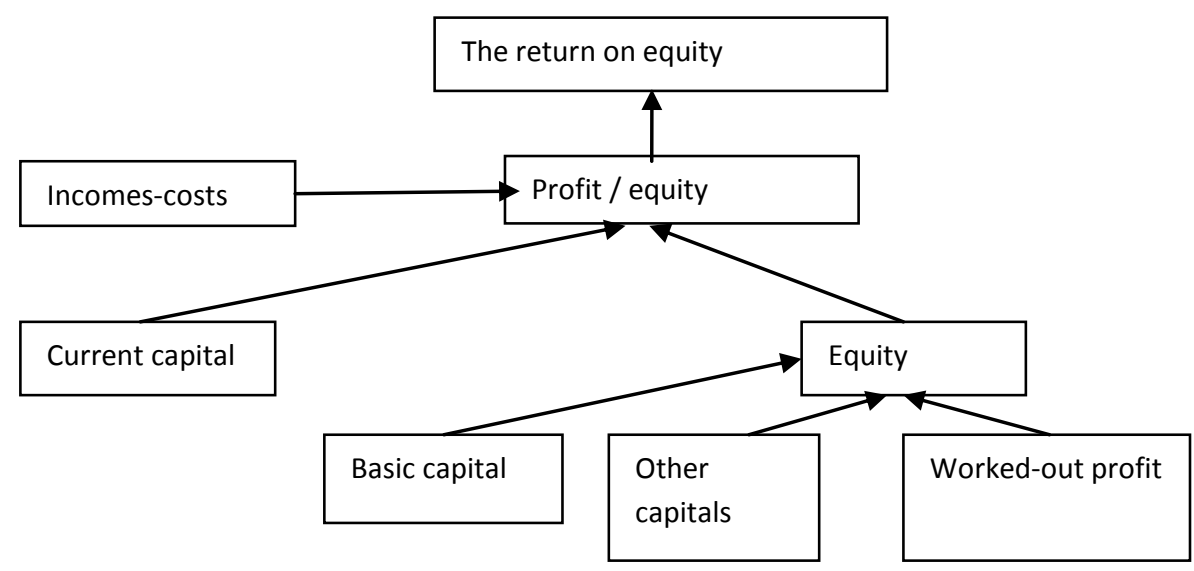

Fig. 5. Determinants of return on equity revenue Source: own study

\section{PURCHASING GROUP AND PROFITABILITY}

Profitability and its level and the size in the company are affected by revenues and expenses. Cost optimization and sales growth cause an increase in profit. Profitability is typically tested using three basic indexes, which indicate the profitability of sales revenue, assets or assets and equity. Thus, depending on the index which will be analyzed, there are additional and specific determinants. The exception is the rate of return on sales, because sales is a factor building the size of the profit, which is present in all three indexes. When observing the operation of purchasing groups, it is clear the purpose of companies forming them. The main objective is to obtain a low purchase price. The purchase price of commercial companies is the highest costs. It is worth, therefore, to take measures that will reduce this group of costs. The simplest action is to obtain economies of scale, i.e. making huge purchases, so the creation of a group of companies the best from the same branch that work together to increase their purchasing power. The manufacturer needs to respect such a group during the negotiations and needs to present them an attractive offer. The economies of scale to the greatest extent is reached in a branch purchasing group. This is due to the lack of divisions within the purchasing group companies into the respective sectors. The effective functioning of units in purchasing groups should bring the following benefits:

- Lower the cost of purchase,

- Increase turnover.

The above mentioned financial benefits arise when in a purchasing group operates the central unit as the non - profit organizations ${ }^{20}$.

\footnotetext{
${ }^{20}$ Zimon, G., (2013)., Plynność finansowa w przedsiębiorstwach tworzacych grupy zakupowe, W: Kopiński A., Kowalik P., (ed.). Prace Naukowe Uniwersytetu Ekonomicznego we Wrocławiu 321 Zarządzanie finansami firm-teoria i praktyka (pp. 68-81), Wrocław: Wydawnictwo Uniwersytetu Ekonomicznego we Wrocławiu
} 
Operations within the branch purchasing groups will have a positive effect on:

- Improvement of the companies competitiveness it will be caused by obtaining low prices of purchased goods and an attractive commercial credit. Low prices and attractive commercial credits offer the opportunity to gain new customers.

- An increase of turnover, it is a derivative of the low price and the ability to offer customers an extended credit.

- Mutual cooperation between the companies making up the purchasing group can reduce the incidence of stocks, which will reduce the cost of lost opportunities.

- Cooperation with the central unit reduces logistics costs.

- Another item of costs that can be reduced are external services, i.e. the costs of telecommunication, legal, consulting, marketing and information technology services.

- The consumption of materials and energy costs are another group where you can observe the decrease in costs e.g. fuel costs, maintenance costs of computer equipment.

- In the companies operating in branch purchasing groups there is a group of costs that is constantly growing. Remuneration costs, here the managers try to keep the reliable staff. Competition in the market is large and to prevent the process of "taking over" workers the remuneration of staff grows.

- Functioning as part of purchasing groups can lead to optimization of inventory levels in the company, which has a positive effect on the profitability of assets.

- For companies operating in branch purchasing groups the receivables are collected at a time or with a slight delay. High regularity of receivables is the result of the favorable terms for trade credit offered to customers. No regular repayments in the period may lead to changes in the conditions offered for commercial credit, so the recipients try to pay on time.

All these advantages for companies operating within the purchasing groups will favorably affect the level of profitability.

\section{CONCLUSIONS}

Activity in purchasing groups are certain limitations as well as costs. The maintenance of the central unit costs. However, a number of advantages and benefits that businesses receive in connection with the operation within the branch purchasing groups allow to develop the desired financial results. High profits, optimization of current assets, all this can improve the profitability of individual financial result. High profitability is very good news for the owners, it is also an important signal for competition indicating a stable financial situation. The purchasing groups appearing in every branch show clearly that it is necessary for small and medium-sized businesses primarily in order to survive but also in order to improve the profitability of their operations.

\section{REFERENCES}

[1] Bogdanienko, J. (ed.)., Organizacja i zarzadzanie $w$ zarysie, Warszawa: WWZ, 2010

[2] Chłodnicka H., Zimon G., Wpływ kosztów upadłości na rentowność podmiotu gospodarczego, W: E. Nowak, M. Nieplowicz, (ed.) Prace Naukowe Uniwersytetu Ekonomicznego we Wrocławiu, z.291, Rachunkowość a controlling, pp.66-81, Wydawnictwo Uniwersytetu Ekonomicznego we Wrocławiu, 2013 
[3] Gabrusewicz W., Analiza finansowa przedsiębiorstwa, PWE , Warszawa 2014

[4] Karpuś P., Zarządzanie finansami przedsiębiorstw’ UMCS Lublin, 2006

[5] Kusak A., Decyzje finansowe firmy. Metody analizy, C.H. Beck, Warszawa 2006

[6] Nowak E., Analiza sprawozdań finansowych, PWE, Warszawa 2005, p.169

[7] Porter M., Porter o konkurencji, Warszawa: PWE, 2001

[8] Waśniewski T., Skoczylas W., Teoria i praktyka analizy finansowej $w$ przedsiębiorstwie, FRR w Polsce, Warszawa, 2004

[9] Wędzki D., Analiza wskaźnikowa sprawozdania finansowego, Kluger, Kraków 2006,

[10]Zimon, G., Wplyw grupy marketingowo-zakupowej na sytuacje $i$ wyniki finansowe przedsiębiorstw, W: Z. Luty, M. Chmielowiec-Lewczuk, (red.). Prace Naukowe Uniwersytetu Ekonomicznego we Wrocławiu nr 390, Rachunkowość, polityka makroekonomiczna, globalizacja pp.284-290, Wrocław: Wydawnictwo UE we Wrocławiu, 2015

[11]Zimon, G., Kapitat obrotowy brutto $w$ przedsiębiorstwach handlowych tworzacych grupy zakupowe, W: I.D. Czechowskiej, R.Pastusiaka (red.). Acta Universitatis Lodziensis, Folia Oconomica 2(300) pp. 319-327, Łódź: Wydawnictwo Uniwersytetu Łódzkiego, Łódź , 2014

[12]Zimon, G., Ptynność finansowa w przedsiębiorstwach tworzacych grupy zakupowe, W: Kopiński A., Kowalik P., (ed.). Prace Naukowe Uniwersytetu Ekonomicznego we Wrocławiu 321, Zarządzanie finansami firm - teoria i praktyka (pp.68-81), Wrocław: Wydawnictwo Uniwersytetu Ekonomicznego we Wrocławiu, 2013

\section{WPLYW GRUPY ZAKUPOWEJ NA RENTOWNOŚĆ PRZEDSIĘBIORSTW HANDLOWYCH}

Celem referatu było przedstawienie jaki wpływ na rentowność przedsiębiorstw handlowych ma funkcjonowanie $w$ ramach branżowych grup zakupowych. W artykule zaprezentowano definicje i istotę grup zakupowych. Dokonano ich podziału oraz szczegółowo przedstawiono jakie korzyści daje przedsiębiorstwom handlowym funkcjonowanie w ramach branżowych grup zakupowych. W artykule przedstawiono rolę i funkcje jednostki centralnej powoływanej przez przedsiębiorstwa działające w grupie zakupowej. Zaprezentowano również bariery z jakimi spotykają się przedsiębiorstwa, które chcą dołączyć do grup zakupowych. W dalszej części referatu omówiono kluczowe zagadnienia związane $\mathrm{z}$ rentownością. Wskazano podstawowe wskaźniki służące do pomiaru stopnia intensywności rentowności. Przedstawiono ich budowa oraz determinanty stopy zwrotu przychodów ze sprzedaży, aktywów i kapitałów własnych. Następnie na przykładzie przedsiębiorstw handlowych działających w branżowej grupie zakupowej przedstawiono jakie udogodnienia otrzymują przedsiębiorstwa handlowe działające w branżowej grupie zakupowej. Najważniejsze korzyści które firmy uzyskują to przede wszystkim niska cena zakupu towarów oraz atrakcyjny okres dla kredytu kupieckiego. Oba te elementy plus efekt skali w dużym stopniu pozwalają przedsiębiorstwom handlowym działającym w branżowych grupach zakupowych na obniżanie kosztów działalności 
operacyjnej i zwiększanie przychodów ze sprzedaży. Zwiększenie sprzedaży i optymalizacja poziomu kosztów w wyniku wspólnego działania pozytywnie wpływa na poziom rentowności przedsiębiorstwa.

Słowa kluczowe: grupa zakupowa, zysk, rentowność, koszty.

\section{DOI:10.7862/rz.2016.hss.78}

Przesłano do redakcji: wrzesień 2016

Przyjęto do druku: grudzień 2016 
